\title{
Identity and Multiplicity in School Buildings' Design
}

\author{
By Pasquale Miano* \\ Bruna Di Palma ${ }^{\dagger}$
}

In the field of architectural design, the topic individual buildings and building types is strictly linked with the double subject identity/multiplicity, a research on pertinence and progressive clarification of an architectural theme developed in a particular place. In this sense, thinking about the project of school buildings means to work on a theme of urban architecture highly consolidated and topical at the same time, in which the school building is interpreted as a public building for excellence. This need emerged clearly during the first decade of the 2000s, a period during which an international line of reasoning on the need to come back to work on the schools as sites for architectural experimentation and to bring the size of this issue to the scale of the city began to develop. In this perspective, starting from the comparison between identity and multiplicity, we intend to work on two parallel fronts: under the general theoretical profile, on how the individual school building reacts to the contemporary urban condition and on how, in relation to a specific urban situation, you can configure a variation of its building type. This second aspect will be detailed starting from our project for a new school in Piano di Sorrento, near Naples in Italy. The definition of the overall composition, starting from the design of an intermediate form of open spaces, the modular spatiality of the individual classrooms, the urban character of auditorium, gym, library and dining hall, to the new perspectives of the connective tissue as a learning landscape, have been investigated in an integrated way, with the aim of establishing innovative school architecture, unitary and complete, integrated with balance in the delicate landscape of the Sorrento's peninsula.

\section{Introduction}

For a long time, the theme of the school buildings' design involved urban parts mostly on the edges or in residual areas of the city. Now it can be re-read and re-set to re-formulate the issues and forms of school campus, new or restored, with new structures and different sizes, and to assign them new roles in the city.

In recent years, this is particularly relevant in the Italian context, where, after some structural reforms of the school organization, a new phase has started: some design experimentations and building interventions are created as an opening to an even wider spread of this issue by which the conditions for a significant change of approach to this theme can be set, in both urbanarchitectural and typological-functional terms. This positive condition can be determined despite the lacking update of the 1975 Ministerial Decree,

* Professor, University Federico II of Naples, Italy.

$\uparrow$ National Research Council of Italy, Italy. 
still in force in Italy, which regulates the size and articulation of different types of schools and that, of course, does not consider the changes in teaching methods, the new composition and needs of several classes and the overall organization of schools, now oriented towards a trend of unification of the various schools' level, before being completely absent.

Today, designing a school in Italy is a very challenging task since, however, in the last thirty years a specific research has not developed and more: more than a work on the school building pertinence and character, at best the focus has been its case and its textures. Starting from the awareness of these difficulties, it is time to deal with a consolidated theme that requires, on the one hand, an appropriate typological functional study, but, on the other, interesting and innovative experiments on articulation of open and closed spaces and on the ability of this kind of buildings to establish a reference point in a person's life, but also to innovate and continually adapt itself to new requirements.

This paper explores both theoretical considerations of general nature and applied repercussion given by the work on a specific context, through the case of the project for the new comprehensive school building (see Figure 1) in Piano di Sorrento, near Naples, ranked as the winner of an international contest design. ${ }^{1}$

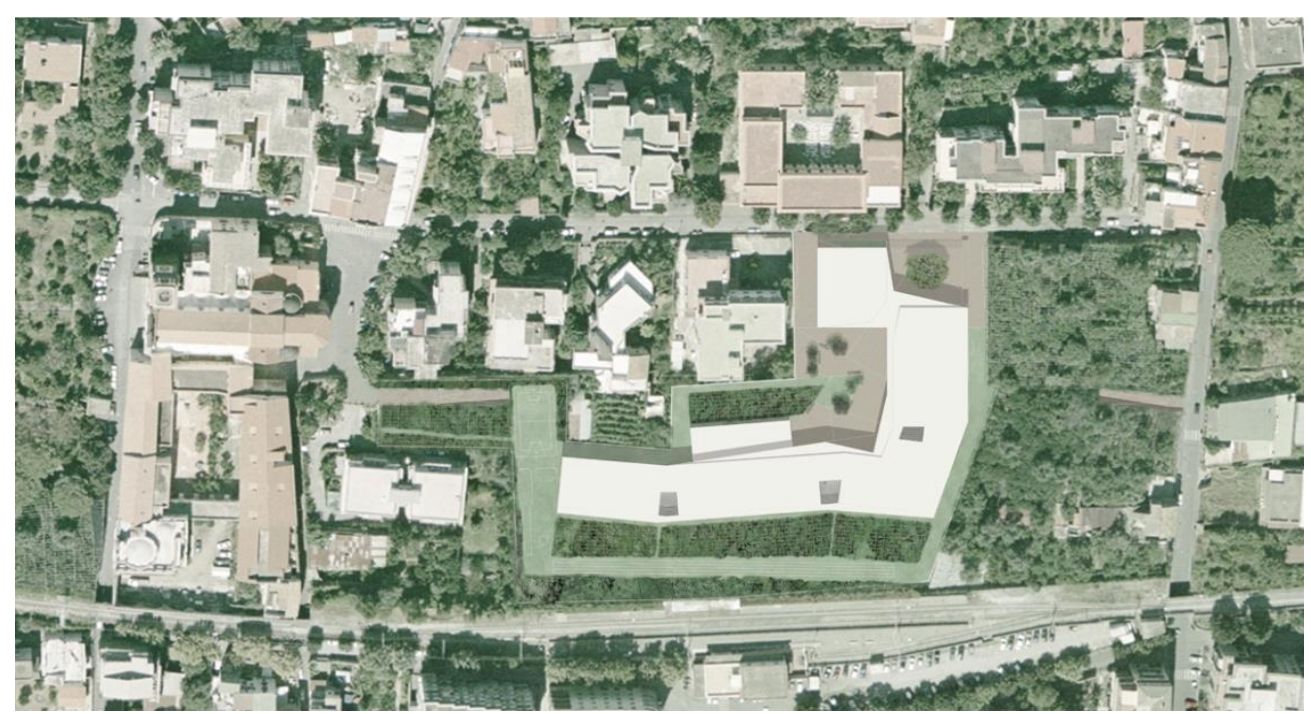

Figure 1. The New School in the Urban Context

Source: Winner Team Drawing for the International Design Competition.

\section{A New Urban Identity}

"Who says that a high-quality public school for all does not pass through the radical re-imagination of school space, starting from the identification of the area where you place it? I do not remember with

1. The International Design Competition was announced by the Municipality of Piano di Sorrento in 2014. The winner team was composed by: Pasquale Miano, Eugenio Certosino, Giuseppe Ruocco, Bruna Di Palma, Felice De Silva, Giampiero Rasulo. 
pleasure even one of the buildings where I worked. Some of them move me. Of course they are the space of a life that has passed. But no one would say: you have to start from there". 2

Some years ago, Domenico Starnone came back, in very striking terms, to the issue of the "position" of the school in the city and its relationships with urban surroundings. It's a very complex question, but it's also essential that needs to be studied again at least for two aspects. Firstly of course, there is the issue of the choice of the location, it touches on many aspects, from urban morphology to the open spaces surrounding the school, which cannot be solved simply in terms of hierarchies, but rather should be addressed through a comprehensive study of contextual relations, whose subject must be re-written entirely. These reports, and the issue here is decisive, must also be measured on the basis of ability to bring inside the school space, the complexity and articulation of urban life and its functions, in this sense Herman Hertzberger says that "the school - is - as a microcity". ${ }^{3}$

Within the complex mechanism of relationships between the school and the city, we must ultimately research a new urban identity of the school, completely different from all those that preceded it in the course of the twentieth century, although if, in the important production of those years, we find absolutely fundamental examples and references. This aspect has been studied and developed in school complexes made by El Equipo Mazzanti in South America, such as, in El Porvenir Kindergarten (Bogota, Colombia 2009), in Flor del Campo School (Cartagena, Colombia 2010), in Timanyui Kindergarten (Santa Marta, Colombia 2011), in Atlantico Kindergarten (Atlantico, Colombia, 2016).

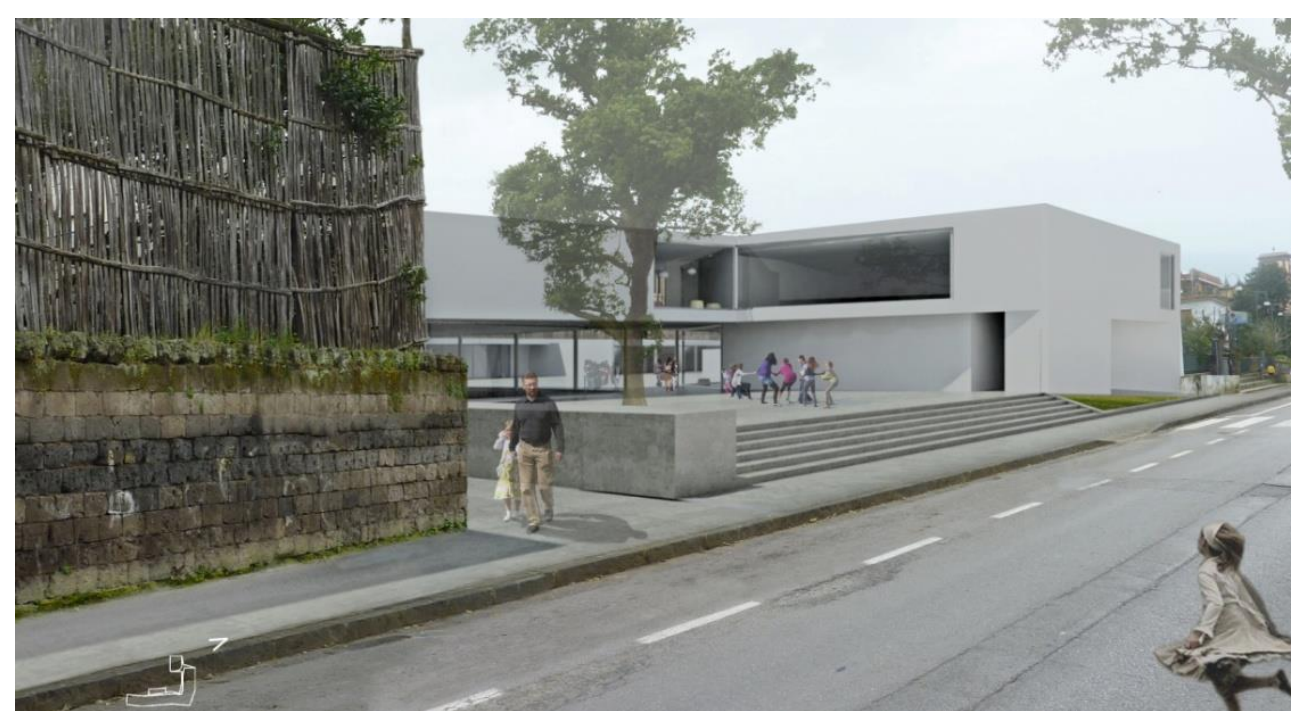

Figure 2. The Volumes' Movement Defines the Entrance to the New School Source: Winner Team Drawing for the International Design Competition.

2. Domenico Starnone. "Le mie scuole," in Casabella 750-751. (2006): 91.

3. Herman Hertzberger, Space and Learning (Rotterdam: 010 Publishers, 2008), 112. 
The theme of identity in a contemporary city cannot be related only about the possibility to identify buildings from an architectural and typological point of view, but it must investigate the possibility to clearly recognize architectural volumes and open spaces structure (see Figure 2) and their ability to generate relations with other elements of the urban fabric, getting stronger than the existing network of public spaces and pathways.

In this perspective, a new school must actually move the weights and balances of urban elements within the city.

In Piano di Sorrento, the new school has been conceived as a public building, with an important rule for the whole community: the gym and the auditorium are accessible to the community in extra school hours, creating a service system for all citizens. This choice translates the concept of civic center also expressed in recent Technical Rules ${ }^{4}$ for the design of school buildings, which do not more address issues related to the size of the spaces, but are more connected with the construction of thematic areas inside the building. But, in the case of the new school in Piano di Sorrento, the term "center" was not interpreted as a hierarchical factor nor as the will of compactness of the architectural structure.

The design work has been primarily addressed to the aim of translating the idea of a school building as a constant stimulus to learning, as encouragement to students to the comprehension of the external world, to aggregation and socialization: an open space, but not indefinite, able to answer to the provocative proposal of Paola Mastrocola to realize, for studying and for the concentration: "a closed place, isolated from the world, where you make your thoughts running". 5 Thinking about both the opposite requirements of opening and closure has been one of the most important aims of the project and this aspect has been recently developed by Aires Mateus in the School centers in Abrantes (Portugal, 2013).

In this sense, after some different design experimentations, we decided to make the architectural system of the new school works in continuity with the urban fabric, in the idea that the building should not be an exception in the urban morphology.

In its typological structure, the new school assumes an urban reference point in the religious San Michele complex and in the near Augustinian monastery. The theme of the sequence "square-entrance space-courtyard" has constituted the starting point to design the new public spaces' system (see Figure 3). This traditional sequence has been renewed and warped, moderating the strong difference between the square and the courtyard and emphasizing the rule of the entrance as transitional space.

4. Technical Rules on the school buildings'design (27/3/2012).

5. Paola Mastrocola, "La scuola raccontata al mio cane," in Casabella 796 (2010): 5. 


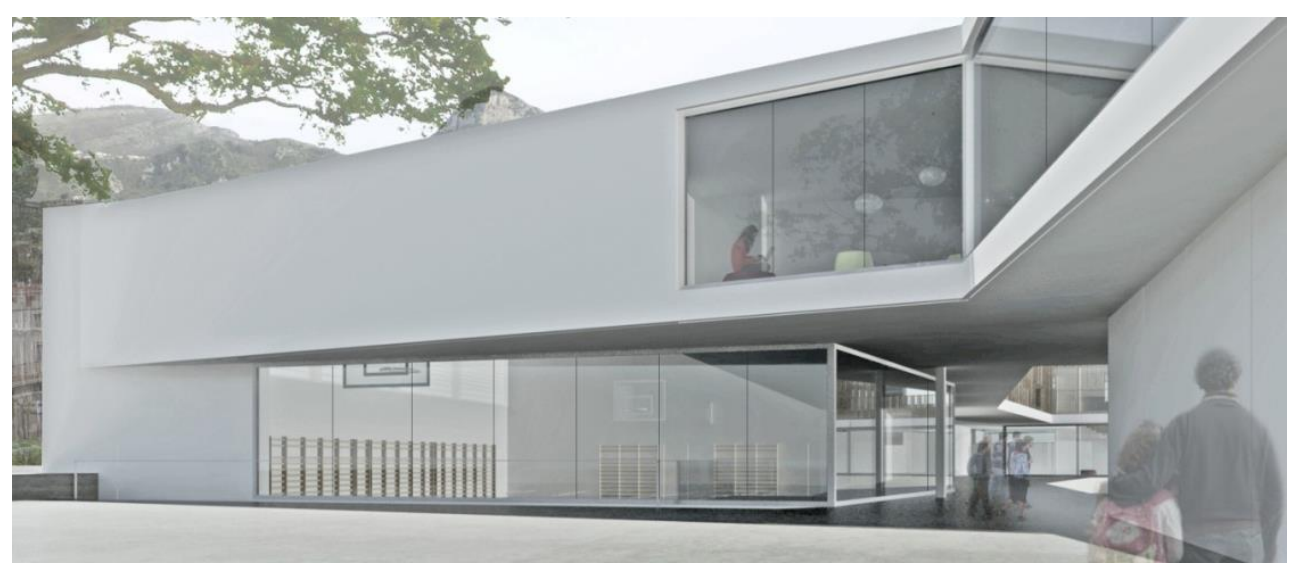

Figure 3. The Entrance to the New School

Source: Winner Team Drawing for the International Design Competition.

A public spaces' system, was obtained, deeply inter-connected and composed mainly by two open courtyards, the first of which, on the main street Carlo Amalfi road, is the natural extension of the public buildings and of the civic center toward the city, while the second, more isolated, is the reference for the design of the classrooms' structure. Between these two main open spaces there are no barriers: their connection is defined by a covered space designed in continuity with the open spaces.

In the inner part of the school (see Figure 4), between the architectural volumes, some big open spaces are defined, usable for teaching, but with the features and the typical structure of an urban park.

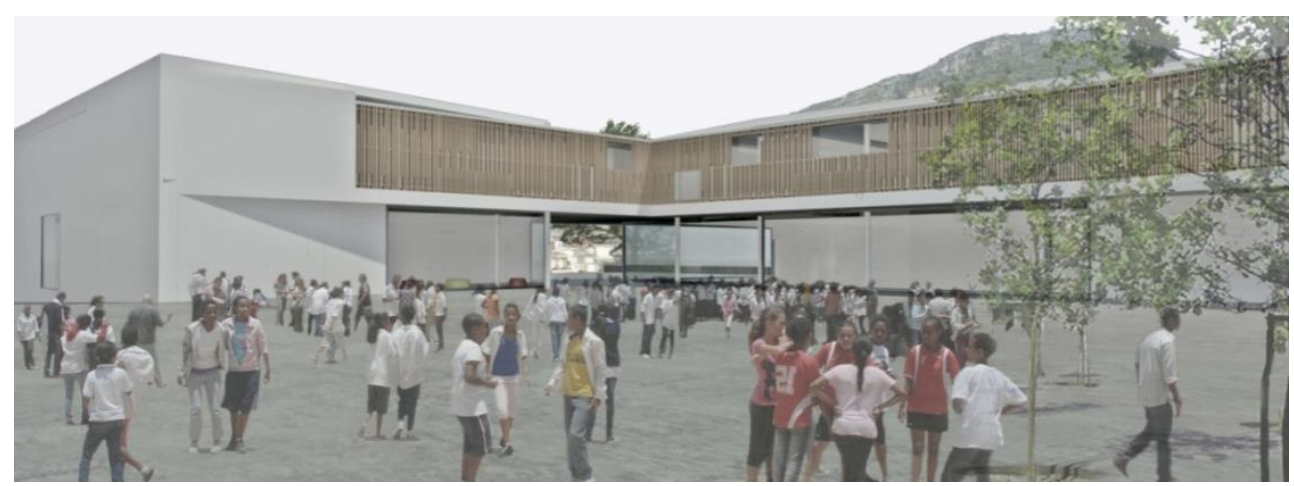

Figure 4. The Inner Courtyard of the New School

Source: Winner Team Drawing for the International Design Competition.

The courtyards' space isn't defined through homogeneous architectural volumes, but through a complex volumetric configuration, deriving from the combination between the paths' system and the other school's spaces, not simple corridors, but a real equipped system, characterized by autonomous volumetric configurations, perfectly recognizable in the general composition (see Figure 5). 


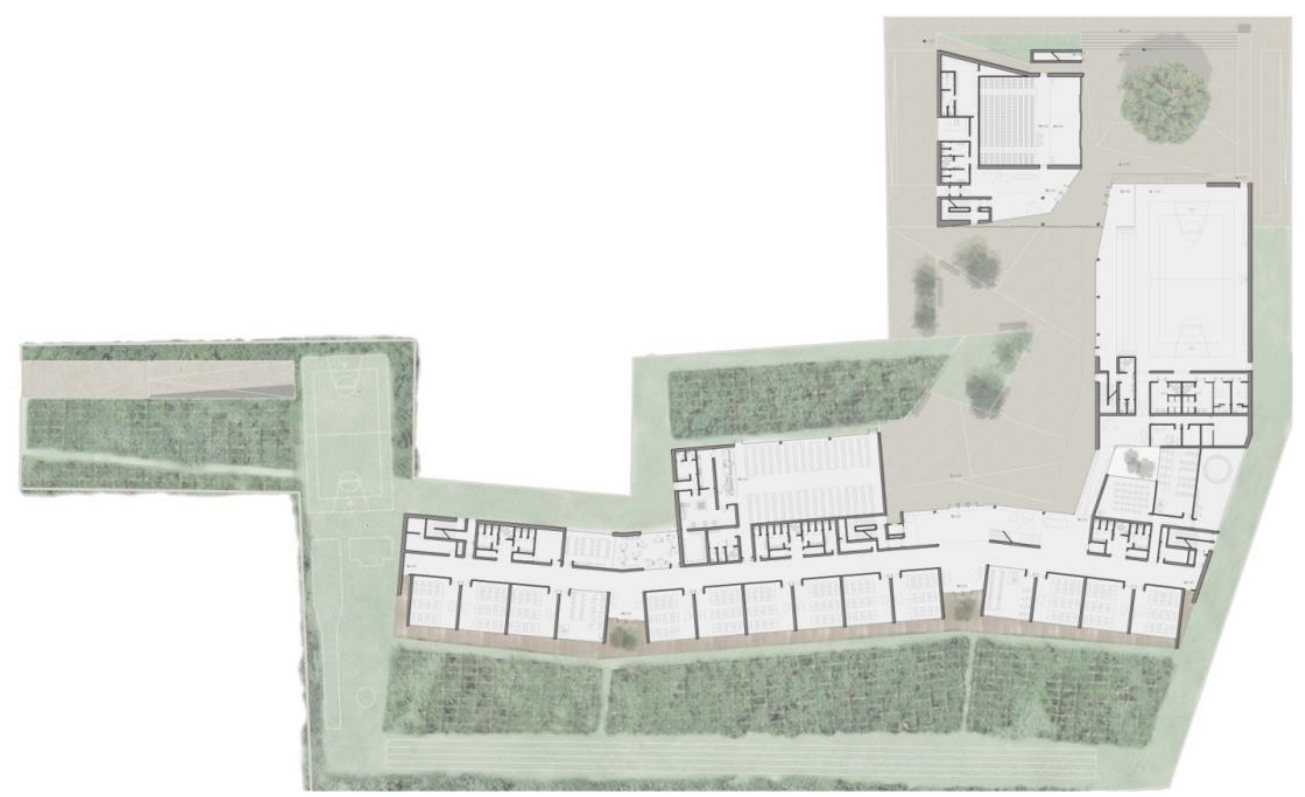

Figure 5. Plan of the Ground Floor of the New School

Source: Winner Team Drawing for the International Design Competition.

\section{Multiplicity of Elements and their Identity}

"The schools you built in Apollolaan, Amsterdam (1980-1983), are similar, but not the equal. Only in one of them the Montessori Method is adopted. In which architectural solutions can this difference be seen?"6 To this question formulated by Chiara Baglione, Herman Hertzberger says "It is true. This shows how Montessori schools and modern schools based on more or less free teaching method, must not be necessarily different each other". ${ }^{7}$ The renewal of teaching methods and the need for building different spaces have a decisive role in the arrangement of the school in Piano di Sorrento. These aspects emphasize the requirement to conceive the school as a complex and heterogeneous system of different parts: each one carries out various tasks, sometimes at an urban level and also for what concerns school's space internal organization.

The needs linked with the renewal of pedagogic systems underline the requirement to give up a unique identification of different parts: without conditioning their shape, new didactic methods emphasize the need of having complex internal spaces.

6. "Learning landscape," Chiara Buglione interviews Herman Hertzberger, in Casabella 750-751 (December 2006 - January 2007): 63.

7. Idid. 
In this perspective, we worked on the issue of school building's identity starting from the theme of multiplicity of parts of which it is composed by, and from their differences. In particular, we focused on some clearly recognizable elements: first of all the atrium (see Figure 6), conceived as the maximum identity element, not only as a representative space, but as a learning space, just like the corridors and the connective space, liven up with lights, recesses, seating spaces, so creating meeting, working and relax areas.

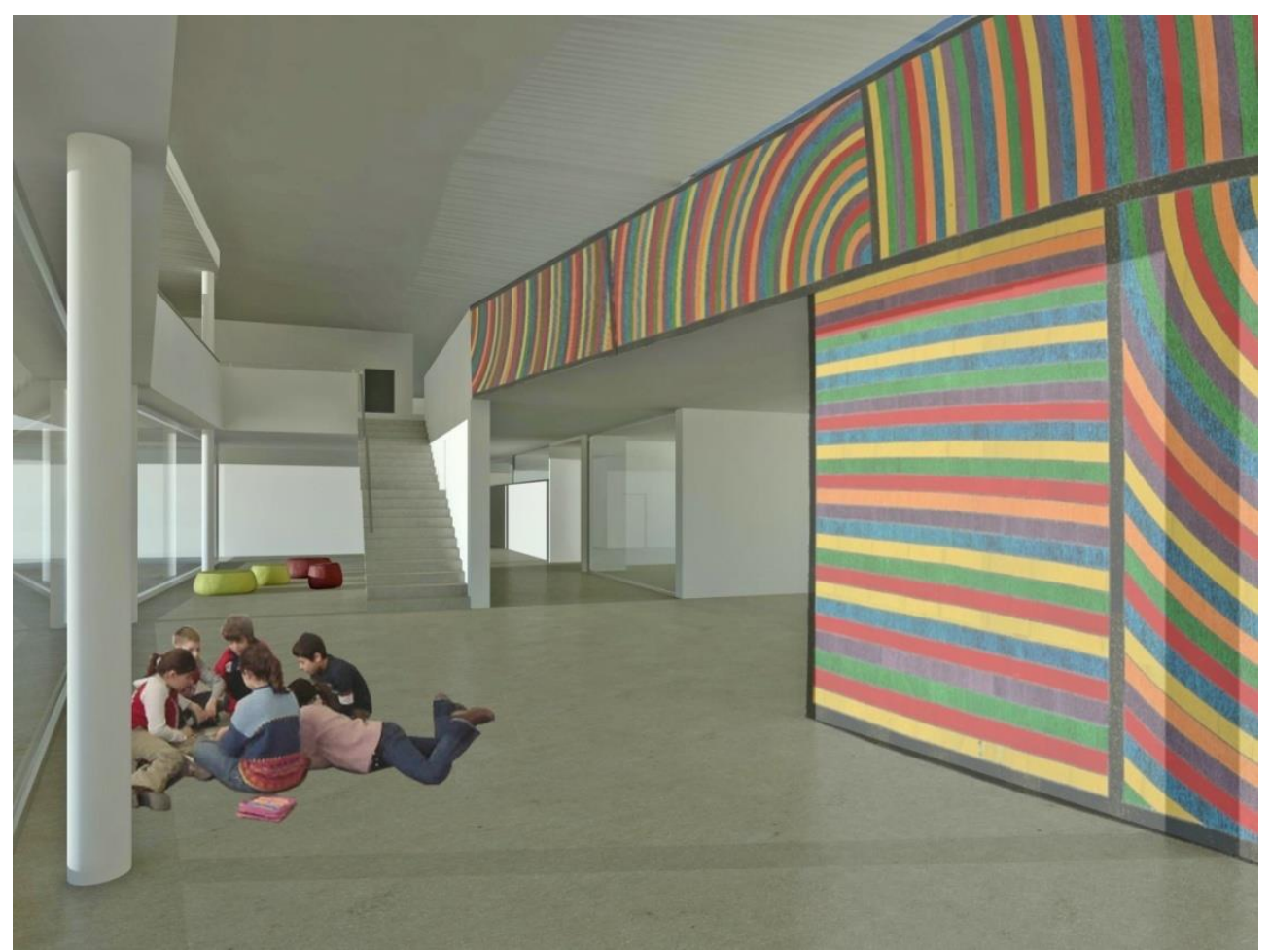

Figure 6. The Entrance Hall of the New School

Source: Winner Team Drawing for the International Design Competition.

At the same time, the second recognizable element, the linear distribution of the connective system-didactic classrooms, has been interpreted as a path that exceeds the traditional logic in corridor design. This is also because new teaching methods need different kind of spaces achievable through flexible equipments. Learning one-to-one, little groups activities, collective discussions, are all different moments of teaching for which the classroom and the special classrooms have been designed.

Finally, also if the new school building has been conceived as a "unicum", the different specialized areas shows particular architectural features and they will be able to be completely autonomous about their arrangement and their use.

The entrance along the Carlo Amalfi road, the main access street, is composed by the open space between the gym (see Figure 7) and the auditorium (see Figure 8), arranged in opposite position; while, towards the opposite edge of the urban area, there is the longitudinal volume of the 
classrooms with large openings of educational spaces oriented to south, and, on the ground level the canteen grafted to north. The two public architectures, the gym and the auditorium, are linked to the school building, but, at the same time, they remain autonomous with their entrances and services equipment. These two parts are connected by the library block and administrative offices, directly reachable both from the classrooms and from the outside. This represents an extremely interesting element in the perspective of increasing the intermediate spaces, not specialized, but decisive in the new school organization.

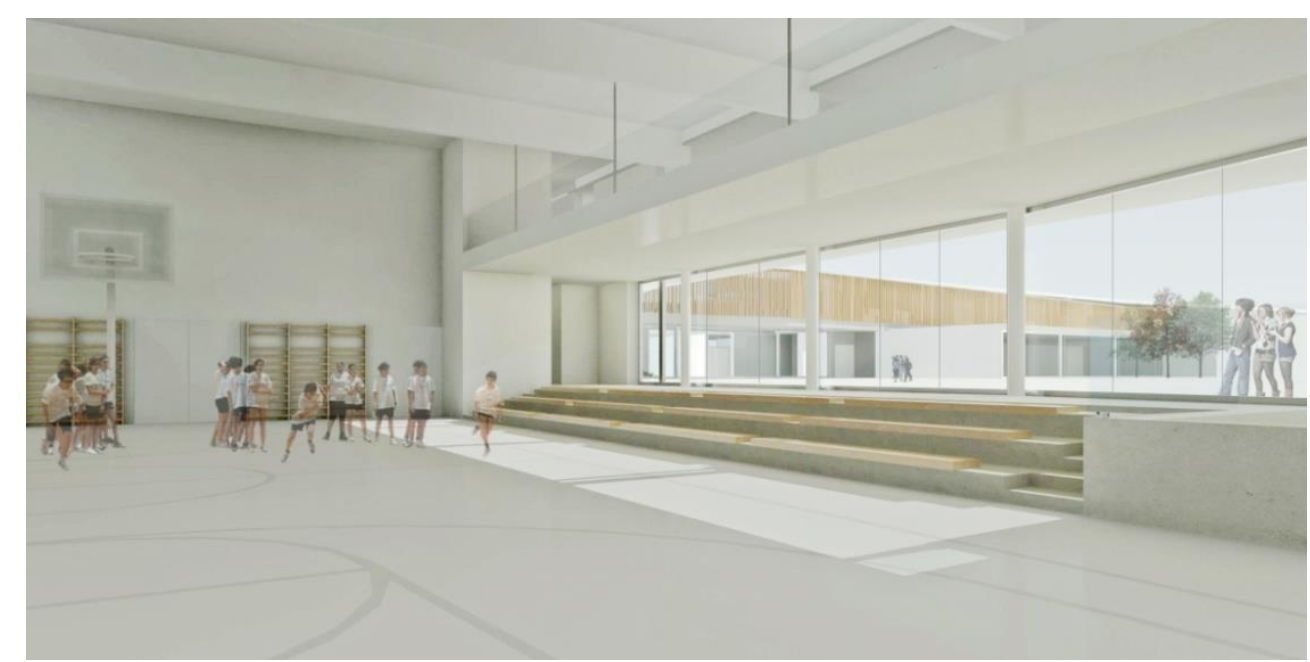

Figure 7. The Gym and its Big Connection with the Inner Courtyard Source: Winner Team Drawing for the International Design Competition.

All these different parts of the school building are highlighted by the architectural disjointed line and are distributed around a huge central open space. It is useful to underline that, through this mechanism, it is possible to smoothly and efficiently connect all parts of the school and ensure optimal arrangement and orientation for the different school activities.

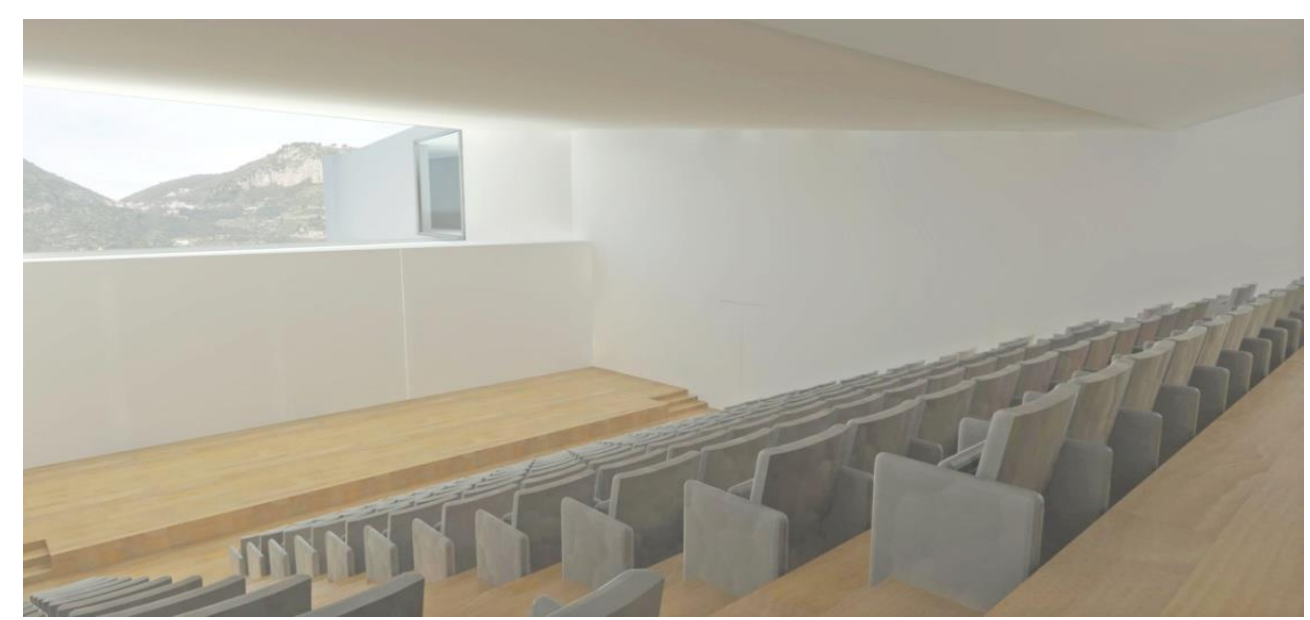

Figure 8. The Auditorium and its Connection with the Landscape

Source: Winner Team Drawing for the International Design Competition. 


\section{Identity (of the Landscape) and Multiplicity (of the References)}

"In the Altamira College built by Matias Klotz in Santiago de Chile (19992000), the small size of the suburban area, compared to the functional program and its big slope, stimulate a typological invention solved in section that, while it reminds the privileged laboratory of typological prototypes grown in the European modern context, functional to gain space and also open areas also in high density regime (from Meyer Petersschule to the Duiker school in Clioostraat), on the other, it also assigns to the landscape the role of a second protagonist with which each claiming to sign or artificial form must find measure". ${ }^{8}$

In Piano di Sorrento, the main architectural character of the most significant historical buildings is defined by their architectural volumes' composition, with their dynamic movement, with their multiple alignments and above all with their very close relationship with gardens and open spaces in which they are integrated. The new school building confirms this structural logic, according to which the building belongs to the landscape and to the open spaces around it, while the landscape is an element of the project, playing different roles, a primary or secondary role in the different situations, while maintaining a common fundamental touch (see Figure 9).

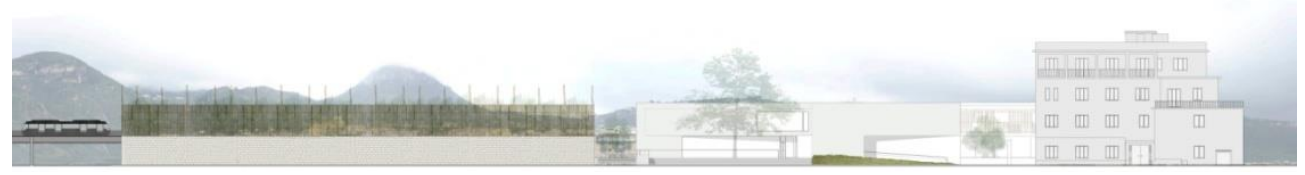

Figure 9. The New School from the Main Street

Source: Winner Team Drawing for the International Design Competition.

The school is organized around an open courts' system. The first open space, along the Carlo Amalfi street has a more public nature, while the second one has an intermediate character between a garden and a square. In the second courtyard there is a citrus trees system, fully integrated in the whole school building space and directly connected to the classrooms and sport area.

This gradual passage continues inside the buildings, where some areas, breaking the sequence of classrooms, are considered as an intermediate element of the architectural composition, between the inside and the outside.

This sequence could continue in other surroundings areas, where it could assumed the feature of a broad green band, made up of citrus trees, gardens and sports facilities, designed as a real urban route.

On the other hand, in the definition of architectural choices and materials of the project of the school building in Piano di Sorrento, references to the local landscape are also involved on other levels: for example, the use of wooden shields re-interprets, in a contemporary language, the shielding

8. Laura Anna Pezzetti, "Paesaggi di fine e inizio secolo per l'educazione," in Architettura per la scuola. Impianto, forma, idea, ed. Anna Laura Pezzetti (Napoli: CLEAN, 2012): 94. 
systems of the citrus groves ("pagliarelle") and the slats of the old shutters (see Figure 10).

Also for the work of art, installed as part of the entrance back wall, the issue was based on the topic of local tradition, by introducing the possibility to realize minimal work with the handicraft wooden inlay technique, combining contemporary forms and languages with traditional techniques.

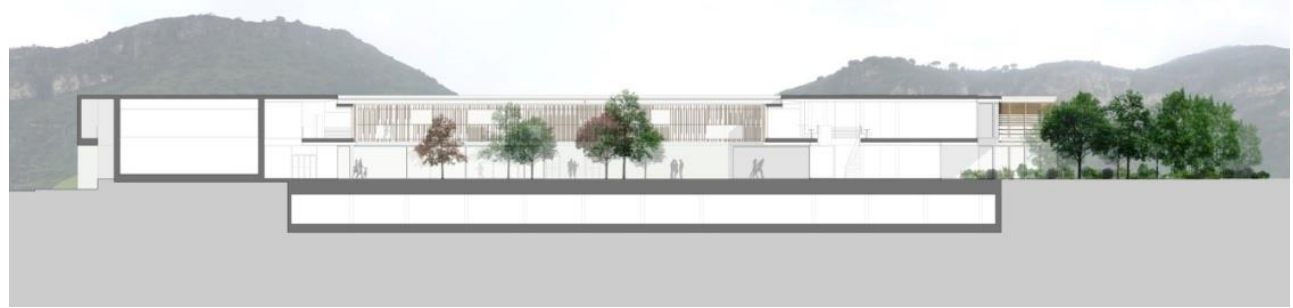

Figure 10. Longitudinal Section of the New School

Source: Winner Team Drawing for the International Design Competition.

\section{An Identity Multiplicity}

"Just go through the entrance, you are warned that the assembly hall - a large double-height space that is the functional and the geometric center of the school - will have its daily revolution, becoming a crowd canteen where will be located one hundred tables folding massed on the walls". 9

In this recent description of the Hunstanton School, designed and built by Peter and Alison Smithson between 1949 and 1954, a fundamental aspect has been highlighted: the multiplicity, ${ }^{10}$ understood broadly as specific peculiarities of a set of spaces, which include various concepts such as flexibility and changeability, can be itself an identity factor. ${ }^{11}$

It is not simply referred to the possibility of pursuing a multiplicity of use, to be able to use spaces in alternative ways, depending on the different situations, which of course constitutes an aspect of great importance. You must also re-think the multiple points of view and perceptions that a school building can remember, "multiplication - that - chase origins and stories [...] reached out to build webs of meaning", ${ }^{12}$ starting from its location in urban landscape with specific characters.

9. Maddalena Scimemi, "Pensieri inglesi - English Thoughts," in Casabella 750-751, (2007): 30 .

10. In one of his American Lessons, Italo Calvino defines the multiplicity as "the guarantee of a not partial truth". See Italo Calvino, Lezioni Americane. Sei proposte per il prossimo millennio (Milan: Arnoldo Mondadori Editore S.p.a., 2014), 115.

11. On the theme of identity as changeable element, as the result of a process and therefore constantly evolving, it seems appropriate to recall the thought of Zygmunt Baumann: "The construction of identity has taken the form of relentless experimentation". See Benedetto Vecchi, Zygmunt Bauman. Intervista sull'identità (Rome-Bari: Editori Laterza, 2003), 85.

12. Alberto Bertagna and Sara Marini, In teoria. Assenze, collezioni, angeli (Macerata: Quodlibet, 2012), 85. 
In this view, a configuration has been created, in which the quality of the place will also be determined by dynamic and diversified movement of the users. They will use the "mostly urban" space, connected to the school building, at the same time and not always in the same way: the same place can be used, for example, as a cinema or to hold small concerts or simply as a place in which stay in. This can be achieved by realizing, the wall of the auditorium near the square as removable partition (see Figure 11).

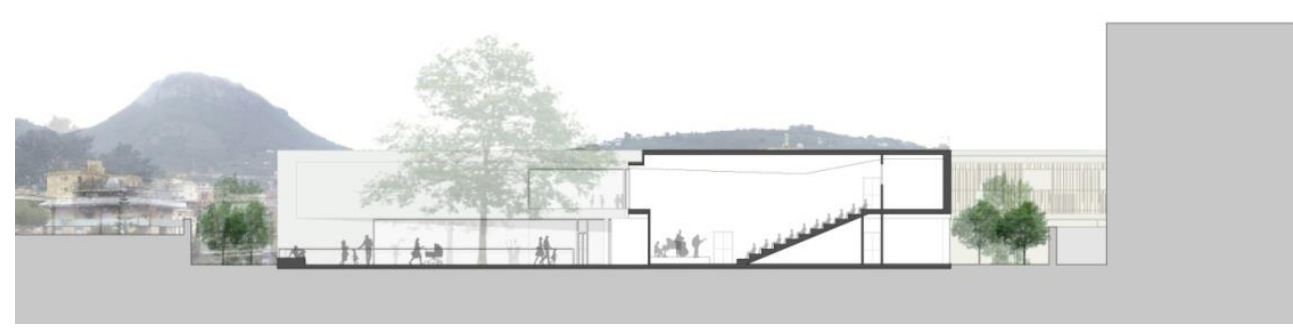

Figure 11. Section of the Auditorium and the Public Open Space Source: Winner Team Drawing for the International Design Competition.

To obtain these aims, we worked to the construction of complex visuals and diversified internal spatial chains that are reassembled in a unified look to the landscape. In this sense, an important part of the design process was the relationship between architecture and landscape through the discourse of internal visuals. Especially for buildings usable for collective events such as the gym and the auditorium, we pursued the aim to exploit the features of the surrounding landscape to characterize, in an innovative way, their interior spaces.

Through large glass diaphragms, the landscape "comes" into the buildings, but, as Sara Marini says, "This is not to fix a framing, but to look to the reality in its transformation and evolution process". ${ }^{13}$ The location of these transparent walls derives from a careful study of visual directions and typological characterization of the buildings, so a more static frontal view has been privileged in the auditorium, while a $360^{\circ}$ visual is articulated on three walls of the gym.

Another important aspect taken into account was the topic of accessibility, studied in reference to two aspects.

The first is linked to the arrivals and departures flows of students accompanying persons with cars, that is a given fact to solve and that cannot be eliminated in a schools' design process and that cannot be underestimated. The flow is redirected in a little square, Largo Annunziata near the new school, where a ramp leads to the basement in which a parking is arranged with direct entries to the school and connected to its open spaces. In the opposite side of the area, through a second ramp, you can get out of the underground parking in a fluid path that diverts the usual route of car. In this way, a continuous path is created; it allows bypassing Carlo Amalfi Street, the main road trough which

13. Sara Marini, Nuove terre. Architetture e paesaggi dello scarto (Macerata: Quodlibet, 2001), 45. 
students will arrive at school, so that, along the same street and near the school, the students themselves could take a break in adequately sized covered spaces. Even the teachers and the administrative staff, who reach the school by car, are welcome in this basement space and, from there, they enter in the different spaces of the building.

A second aspect is related to the pedestrian flow of students. These are welcomed by the double open courts' system along Carlo Amalfi Street which then becomes the reference axis for the entrance to the atrium level and to the gym and the auditorium-assembly hall. The double courts' system, one more public and the other more internal (see Figure 12), also represent the large urban space that gathers students at the exit. The connection system between parking and entrance areas has been organized in such a way as to guarantee the autonomy of the different flows, with particular reference to the independence of the auditorium and the gym. The flows' study has generated a reflection on the spaces, on their stability and their variability and especially on the creation of crossing spaces through the school building.

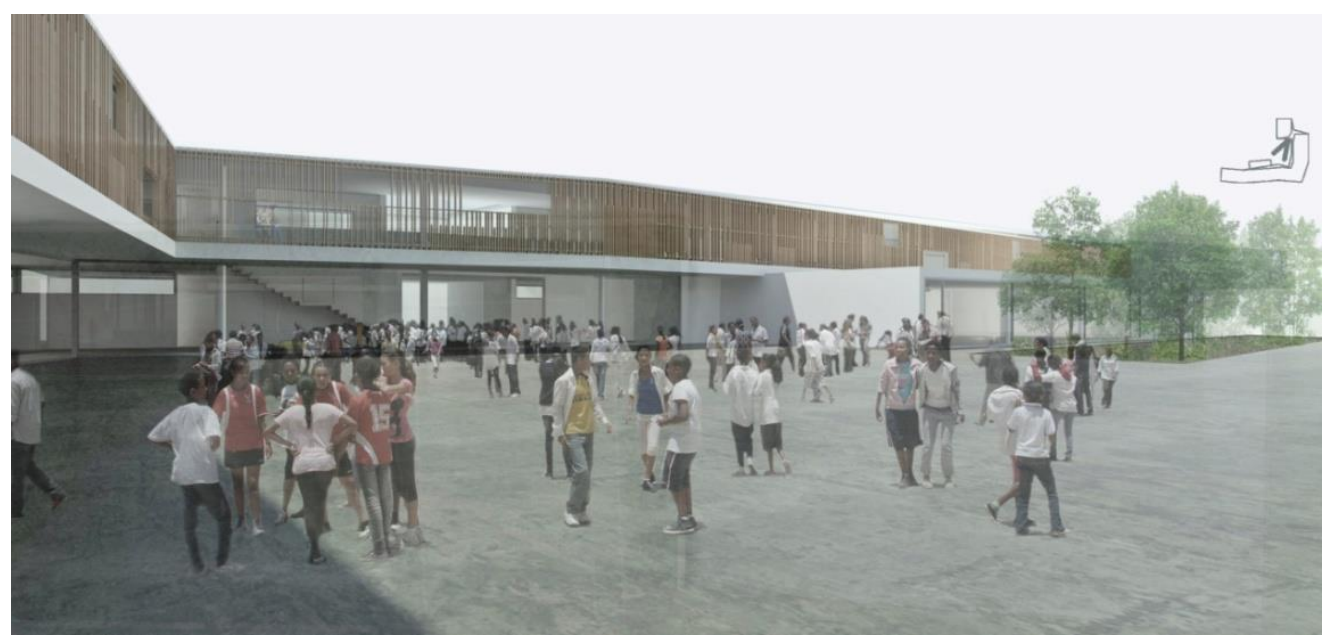

Figure 12. The Inner Courtyard

Source: Winner Team Drawing for the International Design Competition.

\section{Conclusions}

The very complex relationship between tradition and innovation that characterizes the educational institution requires a great architecture's capacity to take on new contents and new tasks and, at the same time, to confirm the representative role of the school in the city, renovating it in its forms and characters.

In this sense, we proceeded to the drafting of the project of the Comprehensive School in Piano di Sorrento: the discussion was on various problems, addressed in connection with the context and with the intervention site, and has come to a design solution capable of guaranteeing the 
achievement of all the goals set at the base of the competition announcement, from those of urban nature to those more specifically spatial and functional.

The definition of the overall composition, the design of an intermediate form of open spaces, the modular spatiality of the individual classrooms, the auditorium, the gym, the library and the canteen urban character, till the new perspectives of the connective tissue as a learning landscape,${ }^{14}$ have been investigated in an integrated manner, with the aim of defining an innovative, unitary and complete school's architecture, included with balance in the delicate landscape of the Sorrento peninsula.

This work allowed the development of a reflection on the different forms and weaves of the concepts of identity and multiplicity in coherence with Carlos Castanheira words about Alvaro Siza's Institute of Education Sciences at the University of Lleidda: "I have not yet visited the Institute of Educational Sciences at Lleida University. I know the project, I saw the images of the site, heard some of the Siza complaints (which is, as always, demanding, unconventional and engaging), but I'm sure that the building will be something different and will soon be visited. I wish all schools were the same: different". ${ }^{15}$

This final result, to which every project aims, passes through a knowledge and pertinence work, which inevitably has to characterize the development of the design theme of the school, a process in which the balance between identity and multiplicity appears decisive.

\section{Bibliography}

Bertagna, Alberto and Sara Marini. In teoria. Assenze, collezioni, angeli [In theory. Absences, collections, Angels.] Macerata: Quodlibet, 2012.

Calvino, Italo. Lezioni Americane. Sei proposte per il prossimo millennio [American lessons. Six proposals for the next millennium.] Milan: Arnoldo Mondadori Editore S.p.a., 1993.

Carlos Castanheira. "All different, al the same." In Alvaro Siza: the Function of Beauty. Edited by Carlos Castanheira. New York: Phaidon, 2009.

Hertzberger, Herman. Lesson for Students in Architecture. Rotterdam: 010 Publishers, 1991.

Hertzberger, Herman. Space and Learning. Rotterdam: 010 Publishers, 2008.

Marini, Sara. Nuove terre. Architetture e paesaggi dello scarto [New lands. Waste architectures and landscapes.] Macerata: Quodlibet, 2002.

Mastrocola, Paola. "La scuola raccontata al mio cane" [The school told my dog]. In Casabella 796 (2010).

Laura Anna Pezzetti. "Paesaggi di fine e inizio secolo per l'educazione." [Landscapes of the end and beginning of the last century for education.] In Architettura per la scuola. Impianto, forma, idea. Edited by Anna Laura Pezzetti. Napoli: CLEAN, 2012.

14. See Herman Hertzberger, Lesson for Students in Architecture (Rotterdam: 010 Publishers, 1991).

15. Carlos Castanheira, "All different, al the same," in Alvaro Siza: the Function of Beauty, ed. Carlos Castanheira (New York: Phaidon, 2009): 202. 
Vol. X, No. Y Miano et al.: Identity and Multiplicity in School Buildings' Design

Scimemi, Maddalena. "Pensieri inglesi - English Thoughts." In Casabella 750-751 (2007).

Starnone, Domenico. "Le mie scuole" [My schools.] In Casabella 750-751 (2006).

Vecchi, Benedetto. (ed.). Zygmunt Bauman. Intervista sull'identità [Zygmunt Bauman. Interview about the identity]. Rome-Bari: Editori Laterza, 2003. 